\title{
Evaluation of resistance to powdery mildew and identification of resistance genes in wheat cultivars
}

\author{
Xianxin Wu ${ }^{\text {Equal first author, } 1}$, Qiang Bian ${ }^{\text {Equal first author, }}{ }^{2}$, Yue Gao ${ }^{1}$, Xinyu Ni ${ }^{1}$, Yanqiu Sun ${ }^{1}$, Yuanhu Xuan ${ }^{1}$, Yuanyin Cao ${ }^{1}$, \\ Tianya Li ${ }^{\text {Corresp. } 1}$ \\ ${ }^{1}$ College of Plant Protection, Shenyang Agricultural University, Shenyang, China \\ 2 National Pesticide Engineering Research Center, Nankai University, Nanjing, China \\ Corresponding Author: Tianya Li \\ Email address: litianya11@syau.edu.cn
}

Wheat powdery mildew, caused by the biotrophic fungus Blumeria graminis f. sp. tritici (Bgt), is a serious disease of wheat worldwide that can cause significant yield losses. Growing resistant cultivars is the most cost-effective and eco-soundly strategy to manage the disease. Therefore, a high breeding priority is to identify genes that can be readily used either singly or in combination for effective resistance to powdery mildew and alos in combination with genes for resistance to other diseases. Yunnan Province, with complex and diverse ecological environments and climates, is one of the main wheat growing regions in China. This region provides initial inoculum for starting epidemics of wheat powdery mildew in the region and other regions and thus, plays a key role in the regional and large-scale epidemics of the disease throughout China. The objectives of this study were to evaluate seedling resistance of 69 main wheat cultivars to powdery mildew and to determine the presence of resistance genes Pm3, Pm8, Pm13, Pm16, and Pm21 in these cultivars using gene specific DNA markers. Evaluation of 69 wheat cultivars with six Bgt isolates showed that only four cultivars were resistant to all tested isolates, indicating that the overall level of powdery mildew resistance of Yunnan wheat cultivars is inadequate. The molecular marker results showed that 27 cultivars likely have at least one of these genes. Six cultivars were found likely to have $P m 3,18$ likely to have $P m 8,5$ likely to have $P m 16$, and 3 likely to have $P m 21$. No cultivar was found to carry Pm13. The information on the presence of the $P m$ resistance genes in Yunnan wheat cultivars can be used in future wheat disease breeding programs. In particular, cultivars carrying Pm21, which is effective against all Bgt races in China, should be pyramided with other effective genes to developing new cultivars with durable resistance to powdery mildew. 
1 Evaluation of resistance to powdery mildew and identification of resistance genes in wheat

2 cultivars

3 Xianxin $\mathrm{Wu}^{1 \#}$, Qiang Bian ${ }^{2 \#}$, Yue $\mathrm{Gao}^{1}$, Xinyu $\mathrm{Ni}^{1}$, Yanqiu Sun ${ }^{1}$, Yuanhu Xuan ${ }^{1}$, Yuanyin $\mathrm{Cao}^{1}$,

4 Tianya $\mathrm{Li}^{1 *}$

$5{ }^{1}$ College of Plant Protection, Shenyang Agricultural University, Shenyang, Liaoning 110866,

6 China

$7 \quad$ 2National Pesticide Engineering Research Center, Nankai University, Tianjin 300071, China

$8 \quad$ \#These authors contributed equally to this work.

$9 \quad$ * Corresponding authors

10 Phone/Fax: +86 248834 2056, litianya11@syau.edu.cn (Tian Ya Li)

\section{Abstract}

12 Wheat powdery mildew, caused by the biotrophic fungus Blumeria graminis f. sp. tritici (Bgt), is

13 a serious disease of wheat worldwide that can cause significant yield losses. Growing resistant

14 cultivars is the most cost-effective and eco-soundly strategy to manage the disease. Therefore, a

15 high breeding priority is to identify genes that can be readily used either singly or in combination

16 for effective resistance to powdery mildew and alos in combination with genes for resistance to

17 other diseases. Yunnan Province, with complex and diverse ecological environments and

18 climates, is one of the main wheat growing regions in China. This region provides initial

19 inoculum for starting epidemics of wheat powdery mildew in the region and other regions and

20 thus, plays a key role in the regional and large-scale epidemics of the disease throughout China.

21 The objectives of this study were to evaluate seedling resistance of 69 main wheat cultivars to 
22 powdery mildew and to determine the presence of resistance genes $P m 3, P m 8, P m 13, P m 16$, and

$23 \quad P m 21$ in these cultivars using gene specific DNA markers. Evaluation of 69 wheat cultivars with

24 six Bgt isolates showed that only four cultivars were resistant to all tested isolates, indicating that

25 the overall level of powdery mildew resistance of Yunnan wheat cultivars is inadequate. The molecular marker results showed that 27 cultivars likely have at least one of these genes. Six cultivars were found likely to have $P m 3,18$ likely to have $P m 8,5$ likely to have $P m 16$, and 3 likely to have $P m 21$. No cultivar was found to carry $P m 13$. The information on the presence of the $P m$ resistance genes in Yunnan wheat cultivars can be used in future wheat disease breeding programs. In particular, cultivars carrying $P m 21$, which is effective against all $B g t$ races in China, should be pyramided with other effective genes to developing new cultivars with durable resistance to powdery mildew.

Keywords: powdery mildew, resistance genes, molecular markers, wheat

\section{Introduction}

Wheat (Triticum aestivum L.) is one of the most important food crops, which plays a very key role in the world food supply and food security, but its production is constantly challenged by various diseases (Ma et al., 2014; Zhang et al., 2017). Powdery mildew, caused by the biotrophic fungus Blumeria graminis f. sp. tritici (Bgt), is one of the most serious diseases limiting wheat production in many regions of the world (Zhang et al., 2016). Breeding and growing resistant cultivars is generally considered to be the most economical, effective, and environmentally friendly method to control this disease (Petersen et al., 2015; El-Shamy et al., 2016). The first

42 powdery mildew $(\mathrm{Pm})$ resistance gene in wheat was found in wheat variety 'Thew' by Australian 
43 researcher Waterhouse in 1930 (Zeller, 1973). Since then, new powdery mildew resistance genes

44 have been identified from common wheat and wheat relatives. In the meantime, the inheritance

45 characteristics and chromosome locations of powdery mildew resistance genes were studied

46 extensively (Bhullar et al., 2010; Brunner et al., 2012; Hanusova et al., 1996). To date, over 91

47 Pm resistance genes, mapped to 61 loci, have been characterized, and new genes are continually

48 described in common wheat and relatives (Hao et al., 2015; Li et al., 2017; Li et al 2019; Tan et

49 al., 2019; Zhang et al., 2017). Many of these Pm genes have been used widely in wheat breeding

50 programs (Li et al., 2019). Unfortunately, the Pm genes only confer resistance to specific Bgt

51 races, and the race-specific nature is not ideal, since virulent mutants of Bgt can escape

52 recognition of the resistance gene and making resistance genes ineffective (Zhang et al., 2017).

53 For instance, the resistance gene $\operatorname{Pm} 8$, in a cluster with $\operatorname{Yr} 9, \operatorname{Lr} 26$, and $\operatorname{Sr} 31$ for resistance to

54 stripe rust, leaf rust, and stem rust, respectively, on 1BL/1RS was transferred into wheat cultivars

55 from 'Petkus' rye in 1970 s, and has a profound impact on wheat disease resistance breeding in

56 the world (Hurni et al., 2014). Since then, a large number of wheat cultivars carrying 1BL/1RS

57 have been released and widely grown in the world due to the resistance to multiple diseases.

58 However, the overuse of the 1BL/1RS translation in breeding and production has resulted in the

59 rapid emergence of new pathotypes with the corresponding virulence genes, which have

60 overcome the resistance genes, leading to serious epidemics of these diseases (Mago et al., 2005;

61 Pretorius et al., 2000).

62 Recently, powdery mildew has become more significant with increased use of nitrogen

63 fertilizer, changes in irrigation, and the increase of global average temperature (Tang et al., 
64 2017). Therefore, cultivars become susceptible more quickly under the high disease pressure and

65 more rapid changes of virulence in the pathogen population. Knowledge of the identity of race-

66

67

68

specific resistance genes in wheat cultivars is a requirement to identify which resistance genes becoming ineffective. The use of molecular marker assisted selection breeding is a quick and easy approach to identify resistance genes. Molecular markers have been used to identify resistance genes against various diseases in wheat. Among various types of markers, simple sequence repeat (SSR) and single-nucleotide polymorphism (SNP) markers have recently been widely used in studying genes for resistance to powdery mildew (Keller et al., 1999; Liu et al., 2002; Wu et al., 2019).

Yunnan Province, located in the southwest of China, has complex and diverse ecological environments and climates. In this region, wheat powdery mildew is very serious and epidemic occurs every year. Because of the disease-favorable environments, Yunnan provides initial inoculum for wheat powdery mildew, stem rust, leaf rust, and stripe rust, playing a key role in the regional spread and large-scale epidemic of the diseases in China (Li et al., 2012; Li et al., 2016). Therefore, assessment of the resistance level of the main production cultivars to these diseases as well as identification of resistance genes in the cultivars can provide a theoretical basis for diseases management by rationally deploying cultivars with various resistance genes in different areas. Resistance to stripe rust in Yunnan wheat cultivars has been studied by Li et al., (2013). In our previous study, resistance to stem rust in main wheat cultivars of the region was also studied ( $\mathrm{Li}$ et al., 2016; Xu et al., 2017). In recent years, the epidemic level of powdery mildew has been increasing in Yunnan (Tang, 2017). Therefore, this study was carried out to 
determine the level of seedling resistance to powdery mildew and to identify $P m$ genes in wheat cultivars use molecular markers. This information will be useful for developing wheat cultivars with durable resistance to powdery mildew.

\section{Materials and Methods}

Wheat cultivars and $P \boldsymbol{m}$ resistance lines. A total of 69 wheat cultivars and breeding lines used in the present study included main cultivars grown in Yunnan province and genetic stocks used in breeding programs, and seeds were provided by Pro. Mingju Li, Institute of Agricultural Environment and Resources, Yunnan Academy of Agricultural Sciences. The pedigrees of the cultivars are listed in Table 1. A set of 37 wheat lines carrying known powdery mildew resistance genes (Table 2) were also used in the present study as $P m$ gene references, and seeds were provided by Prof. Yilin Zhou, State Key Laboratory for Biology of Plant Diseases and Insect Pests, Institute of Plant Protection, Chinese Academy of Agricultural Sciences.

Isolates of B. graminis f. sp. tritici. Six isolates of B. graminis f. sp. tritici with different virulence patterns were used to evaluate resistance in the wheat cultivars and breeding lines. These isolates were selected from the collection of the Plant Immunity Institute, Shenyang Agricultural University, China. Their virulence/avirulence patterns to the 37 wheat differentials carrying known $P m$ genes are shown in Table 2.

Evaluation of seedling resistance. The 69 wheat cultivars and breeding lines were evaluated in the seedling stage for resistance to powdery mildew using the six Bgt isolates in the greenhouse at the College of Plant Protection, Shenyang Agricultural University, suing the method described in a previous study (Xiang et al., 1994). About 10 seeds of each cultivar were 
106 sown in a pot of $12 \mathrm{~cm}$ in diameter. Highly susceptible cultivar Chancellor was used as a control 107 for evaluating uniformity of inoculation. Plants in different trays were inoculated with the six Bgt 108 isolates separately, and each tray was covered with glass shroud to avoid cross infection of 109 different strains after inoculation. When the primary leaves were fully expanded (about 10 days 110 after planting). When the susceptible cultivar Chancellor was heavily infected, about 10 days 111 after inoculation, infection types (ITs) were recorded. A 0-to-4 ITs scale was used for recording 112 the host response to infection ( $\mathrm{Si}$ et al., 1987), where $0=$ no visible symptoms; 0 ; = 113 hypersensitive necrotic flecks; $1=$ minute colonies with few conidia produced; 2 = colonies with 114 moderately developed hyphae, but few conidia; $3=$ colonies with well-developed hyphae and 115 abundant conidia, but colonies not joined together; and $4=$ colonies with well-developed hyphae and abundant conidia, and colonies mostly joined together. ITs $0-2$ were considered as ' $R$ ' 117 (resistant), and ITs 3-4 as 'S' (susceptible).

118 DNA extraction and PCR amplification. Genomic DNA was extracted from 100 mg young 119 leaves of seven-day old seedlings from each cultivar, using a DNA extraction kit (Sangon Biotech, Shanghai, China). Pm-gene specific primers were synthesized by Shanghai Biotech Biotech Co., Ltd, China (Table 3). Polymerase chain reactions (PCR) were carried out using a S1000 ${ }^{\mathrm{TM}}$ Thermal Cycler in $25 \mu \mathrm{L}$ volume, including $2 \mu \mathrm{L}$ of $50 \mathrm{ng} \cdot \mu \mathrm{L}^{-1}$ DNA, $1 \mu \mathrm{L}$ of 10 $\mu \mathrm{mol} \cdot \mathrm{L}^{-1}$ of each primer, $2.5 \mu \mathrm{L}$ of $10 \times$ buffer $\left(\mathrm{Mg}^{2+}\right), 0.2 \mu \mathrm{L}$ of $5 \mathrm{U} \cdot \mu \mathrm{L}^{-1}$ Taq polymerase, and $0.5 \mu \mathrm{L}$ of $10 \mathrm{mmol} \cdot \mathrm{L}^{-1}$ deoxyribonucleoside triphosphates. The PCR procedure was as follows: $94^{\circ} \mathrm{C}$ for $5 \mathrm{~min}, 30$ cycles of $94^{\circ} \mathrm{C}$ for $45 \mathrm{~s}, 60^{\circ} \mathrm{C}$ for $45 \mathrm{~s}$, and $72^{\circ} \mathrm{C}$ for $1 \mathrm{~min}$, followed by the 
127

128

129

130

131

132

133

134

135

136

137

138

139

140

141

142

143

144

145

146

147

\section{Results}

Wheat seedling resistance to $\boldsymbol{B}$. graminis f. sp. tritici. The powdery mildew infection types of 69 main wheat cultivars and breeding lines to all tested isolates were presented in Table 4. Five wheat cultivar, De 4-8, Kunmai 4, Yixi 2003-64, Yimai lines 2003-13, and Yimai lines 2003-27 were resistant (ITs 0-2) to all tested isolates at seedling stage, accounting for only 5.8\% of the tested cultivars and breeding lines. The remaining 64 wheat cultivars were susceptible to one or more tested isolates (Fig. 1, Table 4).

Molecular identification of Pm3. Pm3 is a single, dominant locus on the short arm of wheat chromosome 1A and contains a more alleles than any other identified Pm loci (Tommasini et al., 2006). Seven specific markers for the Pm3 alleles (Pm3a - Pm3g) based on nucleotide polymorphisms of coding and adjacent noncoding regions were used to identify Pm3 alleles in the wheat cultivars. The specific fragment of 624-bp for Pm3a was amplified in the positive control Asonsan/8cc that is known to carry Pm3a and six cultivars (Fengmai 35, Jing 0202, Liangmai 4, Wenmai 11, Yumai 3, and Yunmai 51), indicating that these cultivars are most likely to carry Pm3a (Fig 2a, Table 5).

Molecular identification of $\boldsymbol{P m} 8$. The best known and widely deployed $\operatorname{Pm} 8$ is located on a 1BL.1RS translocation in hexaploid wheat. It was originally derived from the introgression of the 1RS rye chromosome from rye cultivar 'Petkus'. A sequence-tagged site (STS) marker, IAG95, was developed to identify $\operatorname{Pm} 8$ (Mohler et al., 2001). Wheat cultivars with the chromatin from 'Petkus' carry the resistance allele amplified as $1050 \mathrm{bp}$ fragment by the IAG95 primer pair. In this study, the positive control 'Kavkaz' (Pm8) and 18 wheat cultivars had the 1050 bp 
148 fragment, indicating that these cultivars are most likely to carry $P m 8$ (Fig 2b).

149 Molecular identification of Pm13. Cenci et al. (1999) amplified a 517-bp specific fragment 150 in cultivars containing the $P m 13$ genes by using STS UTV14F/R primers. A 517-bp fragment 151 was amplified in the wheat line R4A $(P m 13)$ as a positive control, and no fragment was

152 153

amplified in the negative control Chancellor as expected. However, no specific fragment was amplified in all tested wheat cultivars and breeding lines, indicating that none of these wheat varieties (lines) are most likely to carry $P m 13$.

Molecular identification of Pm21. Liu et al. (1999) detected a 1265-bp fragment in Yangmai 5/Sub-6V (Pm21) by amplification using the STS 1265 marker of Pm21. In our study, this specific fragment was amplified in the $P m 21$ positive control, but not in the susceptible control Chancellor. This gene was also detected in cultivars Kunmai 4, Yixi 2003-64, and De 4-8, but not in the rest of the cultivars and breeding lines, indicating that these three Yunnan cultivars are most likely to contain Pm21 (Fig. 2c).

Molecular identification of Pm16. SSR marker Xgwm159 for Pm16 developed by Chen et al. (2005) was used to test wheat cultivars and breeding lines. PAGE (polyacrylamide gel electrophoresis) showed that the fragment amplified by the varieties containing Pm16 was about 201-bp, while the fragment amplified by the varieties without Pm16 was about 190-bp. Cultivars Yunmai 39, Yunmai 42, Yunmai 47, Feng 1124 and Fengyin 03-2 had the same fragment as the positive control of the Pm16 single-gene line indicating that these five cultivars are most likely to contain Pm16 (Fig 3). Discussion

Since the 1970s, wheat powdery mildew has been prevalent all over the world, causing different 
169

170

171

172

173

174

175

176

177

178

181

182

183

184

185

186

187

188

189

degrees of economic losses every year. Developing powdery mildew resistant cultivars has always been an important breeding goal of wheat. Powdery mildew has been well controlled, and the losses caused by the disease have been reduced in different stages of history. However, in recent years, wheat powdery mildew has been increasing as a result of losses of varietal resistance caused by the high heterogeneity and frequent virulence changes in the pathogen population. Many wheat cultivars planted at present show a trend of high susceptibility to powdery mildew. Therefore, it is urgent to improve resistance to powdery mildew. In the present study, the resistance level of wheat cultivars in Yunnan province to six Bgt isolates was evaluated. The results showed that most of tested wheat cultivars were highly susceptible to Bgt, indicating that effective genes are lack in Yunnan cultivars. In addition, currently effective genes (Pm13, Pm16, and Pm21) to Bgt in Chinese wheat cultivars are in very low frequencies as only four cultivars contain Pm16, and 3 cultivars contain Pm21, while no cultivars contain Pm13. Therefore, in order to improve the resistance level of wheat cultivars to powdery mildew, it is necessary to pyramid some other effective genes into new cultivars.

The Pm3 locus was one of the first described loci for resistance to powdery mildew (Briggle and Sears 1966). Some of the resistance alleles have been widely used in wheat breeding programs in the many countries including China, and some of the resistance alleles have remained effective (Bougot et al., 2002; Wu et al., 2019). Liu et al. (2019) reported about 95.1\% wheat cultivars from Heilongjiang Province carrying Pm3. In the present study, we identified the gene in only six cultivars grown in Yunnan (Fengmai 35, Jing 0202, Liangmai 4, Wenmai 11, Yumai 3, and Yunmai 51). 
The gene $P m 8$ on $1 \mathrm{BL} / 1 \mathrm{RS}$ was transferred into many bread wheat cultivars from 'Petkus' rye

191

192

193

194

195

196

197

198

199

200

201

202

203

204

205

206

207

208

209

210

(Graybosch, 2001). The 1BL/1RS translocation has been play an important role in wheat disease

resistance breeding in the world, because this locus is closely linked to disease resistance genes, including $\operatorname{Sr} 31, \operatorname{Lr} 26$, and $\operatorname{Yr} 9$ for resistance to stem rust, leaf rust, and stripe rust, respectively. It is reported that more than wheat cultivars grown in $50 \%$ of the total wheat planting areas in China carry this translocation ( $\mathrm{Li}$ et al., 2011). Our results showed that eighteen wheat cultivars contain $P m 8$, accounting for $26.1 \%$ of the tested cultivars from Yunnan. Conversely, pedigree tracking indicated that resistant stocks carrying $P m$, such as 'Kavkaz' and 'Lovrin' lines, were widely used in wheat breeding in Yunnan Province, suggesting the origin of resistance genes in these wheat cultivars ( $\mathrm{Li}$ et al., 2016). Our results were consistent with previous reports. For example, Li et al. (2011) found that the frequency of 1BL/1R translocation in Huang-Huai wheat region was as high as 59\%. In addition, no virulent races of $P$. graminis $\mathrm{f}$. sp. tritici to resistance gene $\operatorname{Sr} 31$ has been found in China. Therefore, this gene will still have an impact on wheat breeding for disease resistance, although the resistance to Bgt has been lost in China. Thus, $\operatorname{Pm} 8$ should be used in combination with other genes for effective resistance to Bgt in wheat breeding programs to maintain the long-term resistance of cultivars.

Gene Pm13 originated from Aegilops longissima and was located on the 6VS of the translocation chromosome T6AL/6VS of wheat/ Aegilops longissima translocation. It is one of the effective resistance genes to powdery mildew in the world including China. Cenci et al. (1999) was first developed the STS linkage marker of Pm13, which is widely used in marker assisted selection breeding. In our previous study, Pm13 was found to be effective in 
211 northeastern China (Wu et al., 2019). However, Pm13 was not found in any of the Yunnan wheat

212 cultivars tested in the present study. Similarly, Li et al. (2009) and Liu (2010) did not detected

$213 P$ Pm13 in any of the cultivars, including 50 and 101 cultivars from different regions of China.

214 Their results, together with our study, indicate that $P m 13$ is absent in Chinese wheat cultivars,

215 and this effective gene should be used in breeding programs.

216 Gene Pm16 was the first wheat powdery mildew resistance genes transferred from Triticum

217 dicoccoides Korn into Triticum aestivum L. and was first reported in chromosome 4A at the

218 earliest (Reader and Miller, 1991). However, subsequent studies did not show a consistent

219 chromosomal location. Wang et al. (2004) reported the gene on 5DS, while Chen et al. (2005)

220 reported it on 5BS. Therefore, multiple markers have been reported for Pm16. However these

221 markers may not be specific. In the present study, the SSR marker reported by Chen et al. (2005)

222 was used, and four cultivars, Yunmai 39, Yunmai 42, Yunmai 47, and Fengyin 03-2, were

223 positive for the marker. The pedigree of Yunmai 39 is Secale cereale L./Fuli wheat/Fticher's, and

224 Yunmai 42 is rust-resistant 782/Secale cereale/Fuli wheat/YKLO-PAM"S". As S. cereale is

225 susceptible to powdery mildew, Pm16 might originate from common wheat Fuli. The genealogy

226 of Yunmai 47 is 852-18/852-181//86-4437-75/3/822-852/785// 842-929/4/Gangu436/5/923-3763.

227 As most of genotypes in this pedigree are breeding line numbers, it is impossible to identify the

228 donor for the powdery mildew resistance gene. Fengyin 03-2 originated from Anmai 5

229 (L9288022-2-1/Xingnong 5) in Guizhou. Zhao et al. (2007) found that Anmai 5 was highly

230 resistant to powdery mildew, so Pm16 in Fengyin 03-2 may come from Anmai 5. The pedigree

231 of Feng1124 is E33/58769-6. E33 is an excellent powdery mildew resistant stock imported from 
232 Mexico and maycontain Pm16.

233 Gene Pm21 is derived from Haynaldia villosa, located on the short arm of chromosome 6V

234 (6VS). As this gene has a wide resistance spectrum of Bgt isolates in the world, it has been

235 widely studied (Cao et al., 2011; Wu et al., 2019). Pm21 provides a high level and stable

236 resistance in different genetic backgrounds. Meanwhile, wheat cultivars that carry this gene

237 usually have excellent other agronomic traits. Therefore, this gene has been widely deployed in

238 Sichuan Basin and southern Gansu since the middle 1990s. Since then, Pm21 has been widely

239 used in different wheat production areas in China (Zhan et al., 2010). Jiang et al. (2014)

240 identified $7.4 \%$ of the tested 118 Chinese cultivars contained this gene using markerScar1265

241 closely linked to Pm21. Our results showed that cultivars Kunmai 4, Yixi 2003-64, and De 4-8

242 contain this gene. Kunmai 4 has ALB" $\mathrm{S}$ "/BOW"S" in its pedigree, and ALB" $\mathrm{S}$ "/BOW"S" is a

243 Chile wheat line highly resistant to powdery mildew. In addition, Li et al. (2012) found Kunmai

2444 was highly resistant to all tested $B g t$ isolates. We found that this cultivar likely have $P m 21$. As

245 the genealogical information is not available for Yixi 2003-64 and De 4-8, we could not identify

246 the $P m 21$ donor in these cultivars. Unfortunately only these three cultivars (4.3\%) potentially

247 have Pm21 among the 69 tested wheat cultivars and breeding lines from Yunnan. Pm21 should

248 be pyramided with other effective genes to developing wheat cultivars with durable resistance to

249 powdery mildew.

250 Conclusions

251 Breeding resistant cultivars is the most cost-effective and eco-soundly strategy to protect wheat

252 from disease. In the present study, the seedling resistance of 69 main wheat cultivars in Yunnan 
253 Province were evaluated using 6 isolates of Bgt. Overall, the seedling resistant level of wheat

254 cultivars to powdery mildew resistance were very poor in Yunnan Province. Base on it, the 255 presence of genes $P m 3, P m 8, P m 13, P m 16$, and $P m 21$ in these cultivars were detected using 256 gene specific DNA markers. Six cultivars were found likely to have $P m 3,18$ likely to have $P m 8$, 2575 likely to have $P m 16$, and 3 likely to have $P m 21$. No cultivar was found to carry $P m 13$. The 258 information on the presence of the Pm resistance genes in Yunnan wheat cultivars can be used in 259 future wheat durable disease breeding programs.

\section{Acknowledgments}

261 We appreciate very much to Prof. Xianming Chen from Department of Plant Pathology, 262 Washington State University, Pullman, WA 99164-6430, USA for critical reading and revising 263 of our manuscript.

\section{Funding}

265 This study was supported by National Natural Science Foundation of China (No. 31701738).

266

267

268

269

270

271

272

273

\section{References}

Bhullar NK, Zhang Z, Wicker T, Keller B. 2010. Wheat gene bank accessions as a source of new alleles of the powdery mildew resistance gene Pm3: a large scale allele mining project. BMC Plant Biol. 10:88.

Bougot Y, Lemoine J, Pavoine MT, Barloy D, Doussinault G. 2002. Identification of a microsatellite marker associated with $P m 3$ resistance alleles to powdery mildew in wheat. Plant Breed. 121:325-329.

Briggle LW, Sears ER. 1966. Linkage of resistance to Erysiphe graminis f. sp. tritici (Pm3) and 
274

275

276

277

278

279

280

281

282

283

284

285

286

287

288

289

290

291

292

293

294

hairy glume $(\mathrm{Hg})$ on chromosome 1A of wheat. Crop Sci. 6:559-561.

Brunner S, Stirnweis D, Diaz QC, Buesing G, Herren G, Parlange F, Barret P, Tassy C, Sautter C, Winzeler M, Keller B. 2012. Transgenic Pm3 multilines of wheat show increased powdery mildew resistance in the field. Plant Biotechno. J. 10:398-409.

Cao SQ, Luo HS, Jin MA, Zhang B, Huang J, Jin SL Jia QZ, Wang XM, Li H, Zhang CJ. 2011. Occurrence characteristics and control strategies of wheat powdery mildew in Longnan wheat region of Gansu Province in 2010. Gansu Agri. Sci. Techno. 31:24-26.

Cenci A, D’Ovidio R, Tanzarella OA, Ceoloni C, Porceddu E. 1999. Identification of molecular markers linked to Pm13, an Aegilops longissima gene conferring resistance to powdery mildew in wheat. Theor. Appl. Genet. 98:448-454.

Chen XM, Luo YH, Xia XC, Xia LQ, Chen X, Ren ZH, Jia JZ. 2005. Chromosomal location of powdery mildew resistance gene Pm16 in wheat using SSR marker analysis. Plant Breed. 124:225-228.

El-Shamy MM, Emara HM, Mohamed ME. 2016. Virulence analysis of wheat powdery mildew (Blumeria graminis f. sp. tritici) and effective genes in Middle Delta, Egypt. Plant Dis. 100:1927-1930.

Graybosch RA. 2001. Uneasy unions: Quality effects of rye chromatin transfers to wheat. $J$. Cereal Sci. 33:3-16.

Hanusova R, Hsam SLK, Bartos P, Zeller FJ. 1996. Suppression of powdery mildew resistance gene Pm8 in Triticum aestivum L (common wheat) cultivars carrying wheat-rye translocation T1BL.1RS. Heredity. 77:383-387. 
295 Hao YF, Parks R, Cowger C, Chen ZB, Wang YY, Bland D, Murphy JP, Guedira M, Brown-

296 Guedira G, Johnson J. 2015. Molecular characterization of a new powdery mildew resistance gene Pm54 in soft red winter wheat. Theor. Appl. Genet. 128:465-476.

Hurni S, Brunner S, Stirnweis D, Herren G, Peditto D, McIntosh RA, Keller B. 2014. The powdery mildew resistance gene $\operatorname{Pm} 8$ derived from rye is suppressed by its wheat ortholog Pm3. Plant J. 79:904-913.

Jiang Z, Wang QL, Wu JH, Xue WB, Zeng QD, Huang LL Kang ZS, Hang DJ. 2014.

Keller M, Keller B, Schachermayr G, Winzeler M, Schmid JE, Stamp P, Messmer MM. 1999. Agronomica Sin. 37:943-954. 
316

317

318

319

320

321

322

323

324

325

326

327

328

329

330

331

332

333

334

335

336

Li J, Wang JH, Ren MJ, Xu RH. 2009. Identification and application of the special marker of Pm13 and Pm21 genes with resistance to powdery mildew in wheat. Guizhou Agri. Sci. 37:1-4.

Li MJ, Duan XY, Zhou YL, Yu YX, Bi YQ, Yang JH, Zhang Q. 2012. Postulation of seedlings resistance genes to powdery mildew in wheat commercial cultivars from Yunnan Province. $J$. Triticeae Crops 32:551-556.

Li MJ. Population genetic structure of Puccinia striiformis f. sp. tritici in Yunnan Province. Dr. thesis, Institute of plant protection, Chinese Academy of Agricultural Sciences, Beijing, 2013. http://en.cnki.com.cn/Article_en/CJFDTOTAL-MLZW20 1205013.htm

Li TY, Cao YY, Wu XX, Xu XF, Wang WL. 2016. Seedling resistance to stem rust and molecular marker analysis of resistance genes in wheat cultivars of Yunnan, China. PLoS One 11:e0165640.

Liu B, li SH, Wang YQ, Hu DW. 2010. Molecular detection of powdery mildew resistance genes in the commercial wheat cultivars in China. Acta Phytophylacica sinica. 37:113-117.

Liu WL, Zhang HJ, Sun Y, Liu DJ, Yang SP, Zhang R, Meng QL. 2019. Detection and analysis of resistance genes of spring wheat to powdery mildew in Heilongjiang Province since the founding of the People's Republic of China. J. Nuclear Agri. Sci. 33:39-47.

Liu ZY, Sun QX, Ni ZF, Yang TM. 1999. Development of SCAR markers linked to the Pm12 genes conferring resistance to powdery mildew in common wheat. Plant Breed. 118:215-219.

Liu ZY, Sun QX, Ni ZF, Nevo E, Yang T. 2002. Molecular characterization of a novel powdery mildew resistance gene Pm30 in wheat originating from wild emmer. Euphytica 123:21-29.

Ma PT, Xu HX, Luo QL, Qie YM, Zhou YL, Xu YF, Han HM, Li LH, An DG. 2014. 
337 Inheritance and genetic mapping of a gene for seedling resistance to powdery mildew in wheat 338 line X39862. Euphytica 200:149-157.

339

340

341

342

343

344

345

346

347

348

349

350

351

352

353

354

355

356

357

Mago R, Miah H, Lawrence GJ, Wellings CR, Spielmeyer W, Bariana HS, McIntosh RA, Pryor AJ, Ellis JG. 2005. High-resolution mapping and mutation analysis separate the rust resistance genes $\operatorname{Sr} 31, \operatorname{Lr} 26$ and $\mathrm{Yr} 9$ on the short arm of rye chromosome 1. Theor. Appl. Genet. 112:4150.

Mohler V, Hsam SLK, Zeller FJ, Wenzel G. 2001. An STS marker distinguishing the ryederived powdery mildew resistance alleles at the Pm8/Pm17 locus of common wheat. Plant Breeding 120:448-450.

Petersen S, Lyerly JH, Worthington ML, Parks WR, Cowger C, Marshall DS, Brown-Guedira G, Murphy JP. 2015. Mapping of powdery mildew resistance gene Pm53 introgressed from Aegilops speltoides into soft red winter wheat. Theor. Appl. Genet. 128:303-312.

Pretorius ZA, Singh RP, Wagoire WW, Payne TS. 2000. Detection of virulence to wheat stem rust resistance gene Sr31 in Puccinia graminis f. sp. tritici in Uganda. Plant Dis. 84:203.

Reader SM, Miller TE. 1991. The introduction into breed wheat of a major gene for resistance to powdery mildew from wild emmer wheat. Euphytica 53:57-60.

Si MQ, Zhang XX, Duan XY, Sheng BQ. 1987. Identification of physiologic race of Erysiphe graminis f. sp. tritici. Scientia Agri. Sinica. 20:64-70.

Tan C, Li G, Cowger C, Carver BF, Xu XY. 2019. Characterization of Pm63, a powdery mildew resistance gene in Iranian landrace PI 628024. Theor. Appl. Gene. 132:1137-1144.

Tang XL, Cao XR, Jiang YY, Luo Y, Ma ZH, Fan JR, Zhou YL. 2017. Effects of climate change 
358

359

360

361

362

363

364

365

366

367

368

369

370

371

372

373

374

375

376

377

378

of on epidemics of powdery mildew in winter wheat in China. Plant Dis. 101:1753-1760.

Tommasini L, Yahiaoui N, Srichumpa P, Keller B. 2006. Development of functional markers specific for seven Pm3 resistance alleles and their validation in the bread wheat gene pool.

Theor. Appl. Genet. 114:165-175.

Wang J. Establishment of SSR molecular markers tightly linked to wheat powdery mildew resistance genes Pm12 and Pm16. Master's Thesis, China Agricultural University, Beijin, 2004. http://www.doc88.com/p-807989413173.html.

Wu XX, Xu XF, Ma DX, Chen RZ, Li TY, Cao YY. 2019. Virulence structure and its genetic diversity analyses of Blumeria graminis f. sp. tritici isolates in China. BMC Evo. Bio. 19:183.

Xiang QJ, Sheng BQ, Zhong YL, Duan XY, Zhang KC. 1994. Analyses of resistance genes of three differential varieties to the isolates of Blumeria graminis f. sp. tritici in wheat. Acta Agric. Boreali-Sin. 9:94-97.

Xu XF, Li DD, Liu Y, Gao Y, Wang ZY, Ma YC, Yang S, Cao YY, Xuan YH, Li TY. 2017. Evaluation and identification of stem rust resistance genes $\operatorname{Sr} 2, \operatorname{Sr} 24, \operatorname{Sr} 25, \operatorname{Sr} 26, \operatorname{Sr} 31$ and Sr38 in wheat lines from Gansu Province in China. Peer J 5:e4146.

Zeller FJ. 1B/1R wheat-rye chromosome substitutions and translocations. In Proc. 4th Int. Wheat Genet. Symposium (Sears, E.R. and Sears, L.M.S, eds). Columbia, MO: University of Missouri, 1973, pp. 209-221.

Zhan HX, Chang ZJ, Yang ZJ, Zhang XJ, Li X. 2010. Sources and evaluation of powdery mildew resistance Genes in Wheat. Chinese Agri. Sci. 26:42-46.

Zhang RQ, Sun BX, Chen AZ, Xing LP, Feng YG, Lan CX, Chen PD. 2016. Pm55, a 
379 developmental-stage and tissue-specific powdery mildew resistance gene introgressed from 380 Dasypyrum villosum into commom wheat. Theor. Appl. Genet. 129:1975-1984.

Zhang Y, Bai Y, Wu G, Zou S, Chen Y, Gao C, Tang D. 2017. Simultaneous modification of 382 three homoeologs of TaEDR1 by genome editing enhances powdery mildew resistance in 383 wheat. Plant J. 91:714-724.

Zhao JH, Shang YF, Wang SJ, Yang CL, Lu XB. 2007. Identification of mult-resistance of 152

385 wheat varieties (strains) in Huang Huai region. J. Triticeae Crops. 27:1123-1127.

Zhu GQ, Chi WJ, Wu XX, Cao YY. 2015. Analysis of genetic diversity and geographic relationship of Blumeria graminis f. sp. tritici in Northeastern wheat region. J. Henan Agri. Sci. 44:77-82. 
Figure 1

Fig. 1. Number of wheat cultivars and breeding lines showing different infections in seedlings when tested with six isolates of Blumeria graminis f. sp. tritici.

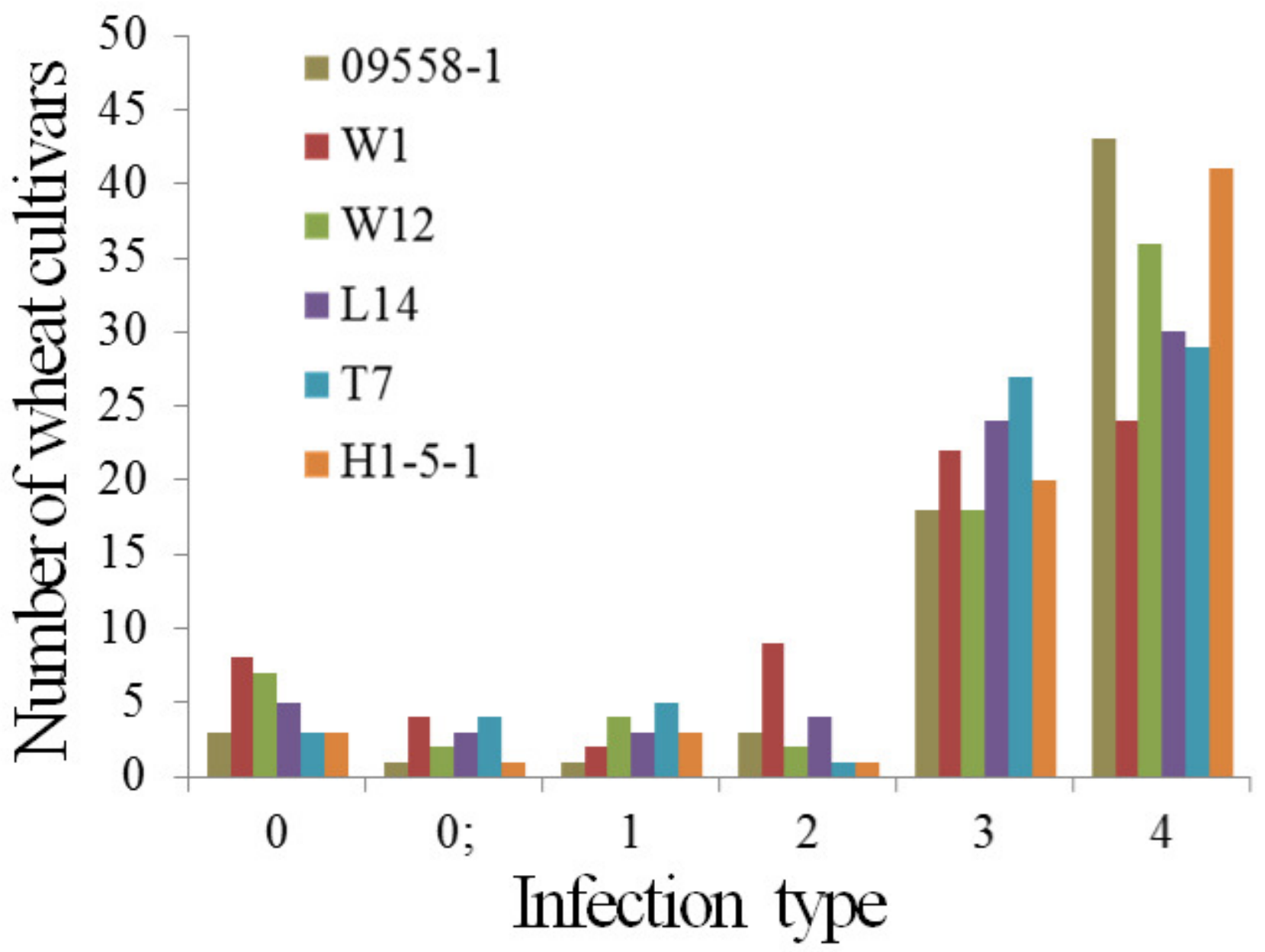




\section{Figure 2}

Fig. 2. Electrophoretograms of primers for different $P m$ genes. The corresponding primers for Pm3a (a), Pm8 (b), and Pm21 (c) were used to screen Yunnan wheat cultivars and breeding lines.

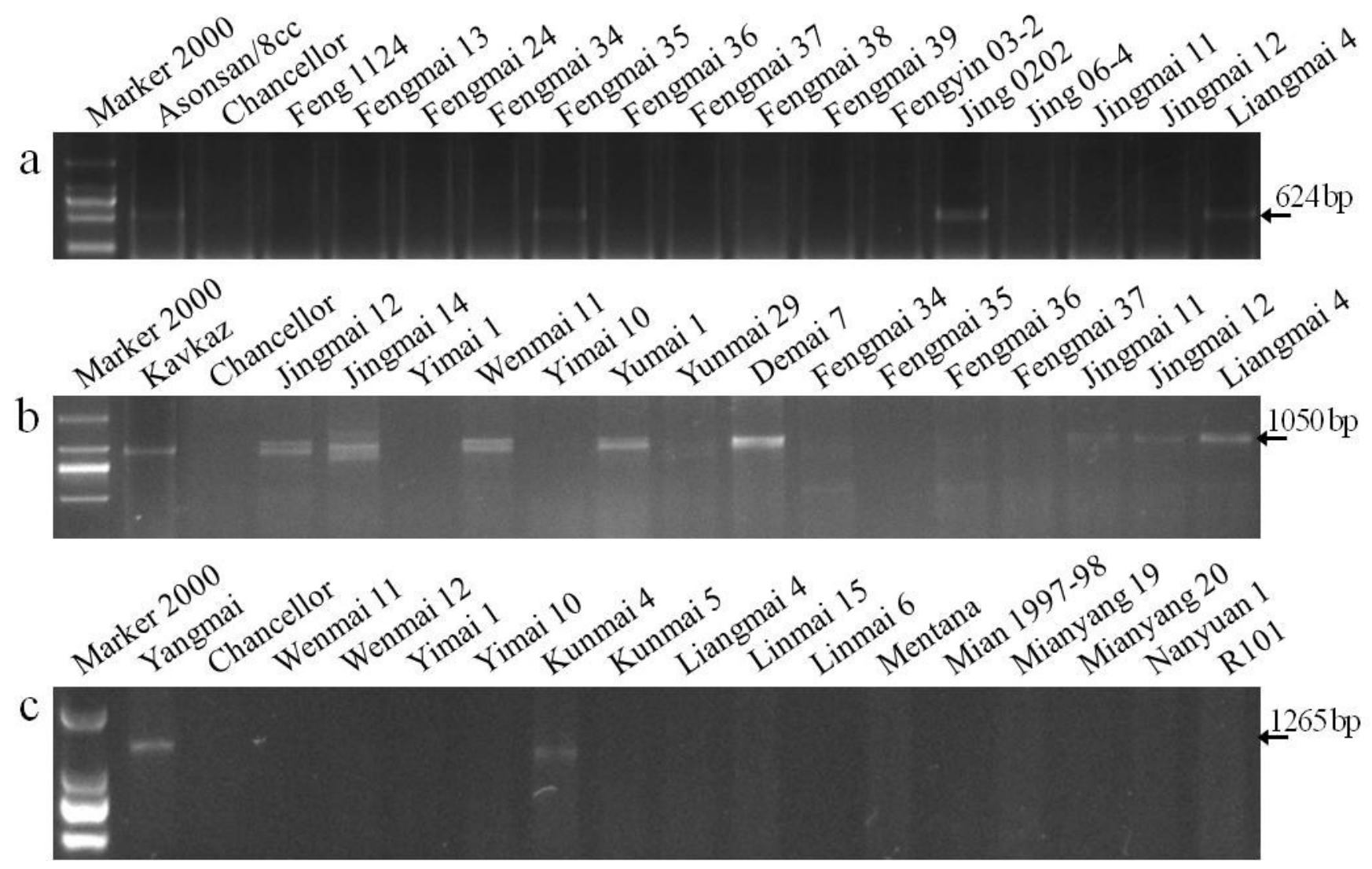




\section{Figure 3}

Fig 3. Amplification result for parts of wheat varieties amplified with premier Xgwm159 of Pm16

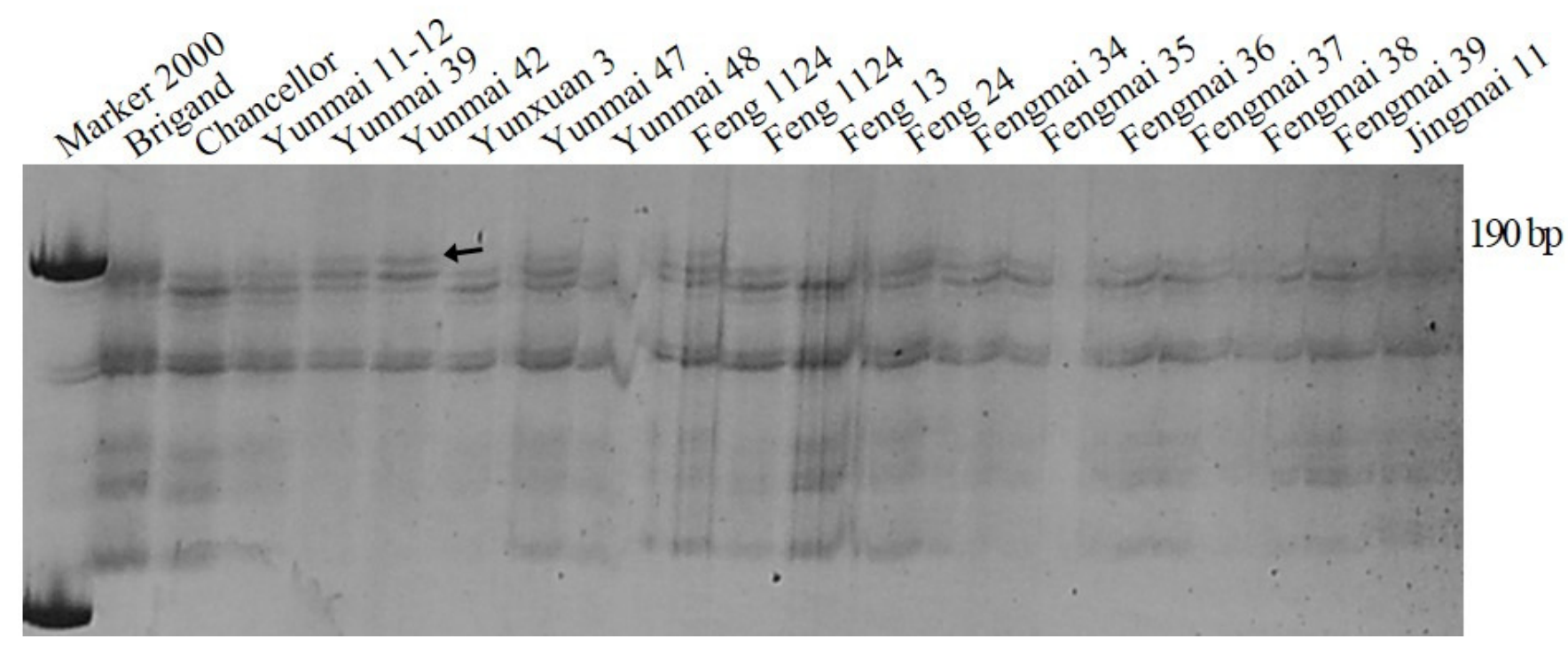




\section{Table $\mathbf{1}$ (on next page)}

Table 1. Pedigrees of 69 wheat cultivars used in this study 


\begin{tabular}{|c|c|c|c|}
\hline Cultivar/line & Pedigree & Cultivar/line & Pedigree \\
\hline $017-10$ & $\begin{array}{l}\text { Bolsena- } \\
\text { 1CH/[SieteCerros/XBVT223//AWX011. } \\
\text { G.48.2/XBVT221] }\end{array}$ & Mianyang 19 & $\begin{array}{l}\text { Selected from Fan } 6 / 70-5858 \text { with systemic } \\
\text { selection }\end{array}$ \\
\hline $02 \mathrm{D} 2-282$ & Yunmai 39/Yunmai 42 & Mentana & Reiti /Wilhelmina// Akagomughi \\
\hline 06D6-6 & Yumai 39/992-3 & Mian1971-98 & $96-18-6 / 92 \mathrm{R} 178$ \\
\hline $91 \mathrm{E} 001$ & Selected from Mexico wheat & Yunmai 43 & Unkonwn \\
\hline Chumai 12 & $\begin{array}{l}\text { Selected from the observation materials } \\
\text { of } 02 d-195 \text { with systemic selection }\end{array}$ & Mianyang 20 & $\begin{array}{l}\text { Selected from } 70-5858 / \text { Fan } 6 \text { with } \\
\text { systemic selection }\end{array}$ \\
\hline De 4-8 & Unknown & Nanyuan 1 & Mentana /Yuannong 1 \\
\hline De $05-81$ & $9213-194 / 9213-4074$ & R101 & AGA/HORK"S" \\
\hline De $08-3$ & Unkownn & R57 & Selected from Mexico wheat \\
\hline Wenmai 12 & $\begin{array}{l}\text { Selected from the hybrid advanced lines } \\
\text { of '0581-1' with systemic selection }\end{array}$ & Wenmai 11 & $\begin{array}{l}\text { Selected from the hybrid advanced lines of } \\
\text { '0581-39' with systemic selection }\end{array}$ \\
\hline Demai 3 & Longchun 2/Mocha & Demai 4 & 782-88/Zhongyin 1022 \\
\hline Demai 5 & Mianyang 11/Yun 80-1 & Yimai 1 & Unknown \\
\hline $\begin{array}{l}\text { Yimai lines } \\
2003-13\end{array}$ & Chuanmai 24/96-16 & Yimai 10 & $\begin{array}{l}\text { Selected from Yimai } 1 \text { with systemic } \\
\text { selection }\end{array}$ \\
\hline Demai 7 & Yunzhi 437/892- 17 & E33 & Selected from Mexico wheat \\
\hline Feng 05-394 & $\begin{array}{l}\text { Selected from Fengmai } 31 \text { 's with single } \\
\text { systemic selection }\end{array}$ & $\begin{array}{l}\text { Yimai lines } \\
2003-27\end{array}$ & $96-23 / 96-14$ \\
\hline Feng 1124 & E33/58769-6 & Yixi 2003-64 & $96-23 / 96-14$ \\
\hline Fengmai 13 & Unknown & Yumai 1 & Xingaibai/Germanic dunmai \\
\hline Fengmai 24 & $\begin{array}{l}\text { Moba 65/Precocious Ajin/Mosha } F_{6} / \\
\text { 750025-12/ Mexico advanced lines } 965\end{array}$ & Fengmai 36 & $\begin{array}{l}\text { Selected from Fengmai } 31 \text { 's with single } \\
\text { systemic selection }\end{array}$ \\
\hline Yunmai 29 & Zhushi Wheat/Fuli Wheat & Yumai 3 & $82-1 / 8334$ \\
\hline Fengmai 34 & 9034M3-2-2/YV91-1167 & Yunmai 101 & $963-8224 / 98042-7$ \\
\hline Fengmai 35 & Fengmai 24//806-14-2-15/85-7421 F1 & Yunmai 11- & NG8319//SHA4/LTRA \\
\hline Fengmai 37 & 9034M8-17/Fengmai 24 & Yunmai 39 & Zhushi Wheat/Fuli Wheat/Fticher's \\
\hline Fengmai 38 & $\begin{array}{l}\text { Momai Lines 91E001/Advanced lines } \\
8941\end{array}$ & Yunmai 42 & Kangxiu 782/Yunmai 29//YKLO-PAM S \\
\hline Fengmai 39 & $\begin{array}{l}\text { Selected from Fengmai } 31 \text { 's with single } \\
\text { systemic selection }\end{array}$ & Yunxuan 3 & $\begin{array}{l}\text { SW8488*2/4/SIN/TRAP\#1/3/KAUZ*2/TR } \\
\text { AP//KAUZ }\end{array}$ \\
\hline Jingmai 11 & $\begin{array}{l}\text { Kavkaz 78-385/Mo 980// Multiparent } \\
\text { mixed pollen }\end{array}$ & Yunmai 47 & $\begin{array}{l}852-18 / 852-181 / / 86-4437-75 / 3 / 822- \\
852 / 785 / / 842-929 / 4 / \text { Gangu 436/5/923-3763 }\end{array}$ \\
\hline Jing 0202 & Jingmia 10/96 Feng 1 & Yunmai 48 & 48 99213/92B-4074 \\
\hline Jing $06-4$ & $849 \mathrm{M}_{2}-11-23 / 7730-1-149$ & Yunmai 51 & $91 \mathrm{~B}-831 / 92 \mathrm{~B}-84$ \\
\hline Fengyin $03-2$ & Unknown & Yunmai 52 & 92R149/963-11185 \\
\hline Jingmai 12 & $7901 / 792364 / / 9118$ & Yunmai 53 & $96 \mathrm{~B}-254 / 96 \mathrm{~B}-6$ \\
\hline Jingmai 14 & Sumai 3/Qing 30// 8619-10 & Yunmai 54 & Yunmai 39/S-792 \\
\hline $\begin{array}{l}\text { Kun 022-222- } \\
1\end{array}$ & $\begin{array}{l}\text { Selected from the advanced lines } 022-222 \\
\text { with systemic selection }\end{array}$ & Yunmai 56 & $\begin{array}{l}\text { Advanced lines 932-625/Advanced lines } \\
822-16-7-3\end{array}$ \\
\hline Kunmai 4 & $\begin{array}{l}\text { Selected from the kunmai } 2 \text { with } \\
\text { systemic selection }\end{array}$ & Yunmai 57 & Screening wheat materials from CIMMYT \\
\hline Kunmai 5 & 992-17/Huelauen & Yunza 5 & $01 \mathrm{Y} 1-1069 / \mathrm{K} 78 \mathrm{~S}$ \\
\hline Liangmai 4 & N1491/N1071 & Yunza 6 & $\mathrm{~K} 78 \mathrm{~S} / 01 \mathrm{Y} 1-608$ \\
\hline Linmai 15 & A122/ (87-5/E232) & Yunza 7 & $\mathrm{~K} 78 \mathrm{~S} / 02 \mathrm{Y} 1-101$ \\
\hline Linmai 6 & 86 Jian 22/84-346 & & \\
\hline
\end{tabular}




\section{Table 2 (on next page)}

Table 2. Infection types of 37 wheat genotypes with known Pm genes to tested isolates of Blumeria graminis f. sp. tritici 


\begin{tabular}{|c|c|c|c|c|c|c|c|}
\hline \multirow{2}{*}{ Cultivars (line) } & \multirow{2}{*}{$P m$ gene } & \multicolumn{6}{|c|}{ Infection types to $B$. graminis f. sp. tritici isolates $^{\mathrm{a}}$} \\
\hline & & 09558-1 & W1 & W12 & L14 & $\mathrm{T} 7$ & $\mathrm{H} 1-5-1$ \\
\hline Aminster/8cc & Pm1 & 4 & 0 & 3 & 4 & 4 & 3 \\
\hline $\mathrm{Ulka} / 8 \mathrm{cc}$ & $\operatorname{Pm} 2$ & 4 & 3 & 4 & 0 & 3 & 4 \\
\hline Asosan $/ 8 \mathrm{cc}$ & $P m 3 a$ & 4 & 0 & 3 & 4 & 4 & 3 \\
\hline $\mathrm{Chul} / 8 \mathrm{cc}$ & $P m 3 b$ & 4 & 0 & 3 & 3 & 4 & 0 \\
\hline Sonora/8cc & $P m 3 c$ & 4 & 3 & 4 & 4 & 4 & 3 \\
\hline Kolibri & $P m 3 d$ & 4 & 0 & 1 & 1 & 4 & 4 \\
\hline W150 & Pm3e & 4 & 0 & 4 & 3 & 4 & 4 \\
\hline Mich.Amber/8cc & $P m 3 f$ & 4 & 4 & 4 & 2 & 4 & 4 \\
\hline Whapli/8cc & $P m 4 a$ & 4 & 1 & 3 & 1 & 4 & 4 \\
\hline Armada & $P m 4 b$ & 4 & 3 & 4 & 3 & 4 & 4 \\
\hline Hope/8cc & $\operatorname{Pm} 5$ & 4 & 1 & 4 & 1 & 4 & 3 \\
\hline Coker983 & $P m 5+6$ & 4 & 2 & 0 & 4 & 0 & 3 \\
\hline Tingalen & Pm6 & 4 & 3 & 1 & 2 & 3 & 2 \\
\hline Coker747 & Pm6 & 4 & 3 & 3 & 3 & 4 & 3 \\
\hline CI14189 & $\operatorname{Pm} 7$ & 4 & 0 & 1 & 3 & 4 & 4 \\
\hline Kavkaz & $\operatorname{Pm} 8$ & 4 & 3 & 3 & 2 & 0 & 0 \\
\hline Kenguia & $\mathrm{Pm} 4+8$ & 4 & 3 & 4 & 3 & 4 & 3 \\
\hline Normandie & $P m 1+2+9$ & 4 & 3 & 1 & 3 & 4 & 4 \\
\hline $\mathrm{R} 4 \mathrm{~A}$ & Pm13 & 0 & 1 & 0 & 0 & 0 & 1 \\
\hline Brigand & Pm16 & 3 & 0 & 3 & 1 & 3 & 4 \\
\hline MIN & Pm18 & 0 & 1 & 2 & 0 & 0 & 1 \\
\hline KS93WGRC28 & $\operatorname{Pm} 20$ & 4 & 3 & 3 & 3 & 4 & 3 \\
\hline Yangmai 5/sub.6v & $\operatorname{Pm} 21$ & 0 & 0 & 0 & 0 & 0 & 1 \\
\hline Virest & $\operatorname{Pm} 22$ & 0 & 0 & 4 & 1 & 0 & 2 \\
\hline line81-7241 & $P m 23$ & 4 & 0 & 3 & 1 & 4 & 3 \\
\hline Chiyacao & $\operatorname{Pm} 24$ & 4 & 3 & 3 & 0 & 4 & 3 \\
\hline $5 \mathrm{P} 27$ & Pm30 & 4 & 3 & 4 & 1 & 4 & 4 \\
\hline Mission & $P m 4 b+m l i$ & 4 & 3 & 4 & 0 & 4 & 4 \\
\hline Maris Dire & $P m 2+m l d$ & 3 & 1 & 4 & 0 & 0 & 3 \\
\hline Xiaobaidongmai & $P m X B D$ & 4 & 1 & 4 & 0 & 1 & 1 \\
\hline Baimian 3 & $P m 4+8$ & 3 & 1 & 3 & 0 & 4 & 4 \\
\hline CI12632 & $P m 4+8$ & 4 & 1 & 4 & 0 & 4 & 3 \\
\hline Maris Huntsman & $P m 2+6+$ & 3 & 4 & 3 & 4 & 1 & 3 \\
\hline Era & - & 4 & 3 & 4 & 0 & 0 & 2 \\
\hline Amigo & Pm17 & 4 & 1 & 1 & 3 & 4 & 4 \\
\hline XX186 & Pm19 & 4 & 3 & 4 & 3 & 4 & 4 \\
\hline Funo & - & 4 & 4 & 4 & 3 & 4 & 4 \\
\hline
\end{tabular}

anfection types: $0=$ no visible symptoms; 0 ; = hypersensitive necrotic flecks; 1 = minute colonies with few conidia;

22 = colonies with moderately developed hyphae, but few conidia; $3=$ colonies with well-developed hyphae and

3 abundant conidia, but colonies not joined together; and $4=$ colonies with welldeveloped hyphae and abundant 4 conidia, and colonies mostly joined together. 


\section{Table 3 (on next page)}

Table 3. Molecular markers linked to resistance genes $P m 3, P m 8, P m 13, P m 6$, and $P m 21$ with their forward and backward primers 


\begin{tabular}{|c|c|c|c|}
\hline Tagged $P m$ gene & Primer & Fragment size (bp) & Primer sequence $\left(5^{\prime}-3^{\prime}\right)$ \\
\hline$P m 3$ & Pm $3 a$ & 624 & $\begin{array}{l}\text { GGA GTC TCT TCG CAT AGA } \\
\text { CAG CTT CTA AGA TCA AGG AT }\end{array}$ \\
\hline Pm8 & IAG95 & 1050 & $\begin{array}{l}\text { AGCAACCAAACACACCCATC } \\
\text { ATACTACGAACACACACCCC }\end{array}$ \\
\hline Pm13 & UTV14F/R & 517 & $\begin{array}{l}\text { CGCCAGCCAATTATCTCCATGA } \\
\text { AGCCATGCGCGGTGTCATGTGAA }\end{array}$ \\
\hline Pm16 & Xgwm159 & 201 & $\begin{array}{l}\text { GGGCCAACACTGGAACAC } \\
\text { GCAGAAGCTTGTTGGTAGGC }\end{array}$ \\
\hline Pm21 & Scar1265 & 1265 & $\begin{array}{l}\text { CACTCTCCTCCACTAACAGAGG } \\
\text { GTTTGTTCACGTTGAATGAATC }\end{array}$ \\
\hline
\end{tabular}

1 


\section{Table 4 (on next page)}

Table 4. Percentagess of susceptible and resistant wheat cultivars to six isolates of Blumeria graminis f. sp. tritici. 


\begin{tabular}{llllll}
\hline \multirow{2}{*}{ Isolates } & \multicolumn{2}{c}{ Susceptible } & & \multicolumn{2}{c}{ Resistance } \\
\cline { 2 - 3 } \cline { 5 - 6 } & Number of cultivars & Percentage (\%) & & Number of cultivars & Percentage (\%) \\
\hline 09558-1 & 61 & 88.4 & 8 & 23 & 11.6 \\
W1 & 46 & 66.7 & 15 & 33.3 \\
W12 & 54 & 78.3 & 15 & 21.7 \\
L14 & 54 & 78.3 & 13 & 21.7 \\
T7 & 56 & 81.2 & 8 & 18.8 \\
H1-5-1 & 61 & 88.4 & 4 & 5.8 \\
All tested isolates & 65 & 94.2 & & & \\
\hline
\end{tabular}

1

2

3 


\section{Table 5 (on next page)}

Table 5. Seedling infection types to Blumeria graminis f. sp. tritici and resistance genes detected with molecular markers 


\begin{tabular}{|c|c|c|c|c|c|c|c|c|c|c|c|}
\hline \multirow{2}{*}{$\begin{array}{l}\text { Cultivars/ } \\
\text { lines }\end{array}$} & \multicolumn{6}{|c|}{ Infection types ${ }^{\mathrm{a}}$} & \multicolumn{5}{|c|}{ Resistance gene } \\
\hline & 09558-1 & W1 & W12 & L14 & $\mathrm{T} 7$ & H1-5-1 & $P m 3$ & $\operatorname{Pm} 8$ & $P m 13$ & Pm16 & $\operatorname{Pm} 21$ \\
\hline $017-10$ & 4 & 3 & 4 & 3 & 3 & 4 & - & - & - & - & - \\
\hline $02 \mathrm{D} 2-282$ & 4 & 4 & 4 & 4 & 4 & 4 & - & - & - & - & - \\
\hline 06D6-6 & 4 & 4 & 4 & 4 & 4 & 3 & - & - & - & - & - \\
\hline 91E001 & 4 & 3 & 3 & 4 & 3 & 4 & - & - & - & - & - \\
\hline Chumai 12 & 3 & 4 & 3 & 4 & 4 & 4 & - & - & - & - & - \\
\hline De 4-8 & 0 & 0 & 0 & 0 & 0 & 0 & - & - & - & - & + \\
\hline De $05-81$ & 3 & 4 & 4 & 3 & 4 & 3 & - & + & - & - & - \\
\hline De $08-3$ & 2 & 0 & 0 & 1 & 0 & 0 & - & - & - & - & - \\
\hline Demai 3 & 4 & 3 & 4 & 3 & 3 & 3 & - & - & - & - & - \\
\hline Demai 4 & 3 & 3 & 4 & 4 & 4 & 4 & - & + & - & - & - \\
\hline Demai 5 & 4 & 4 & 4 & 3 & 3 & 4 & - & - & - & - & - \\
\hline Demai 7 & 4 & 4 & 4 & 4 & 4 & 4 & - & + & - & - & - \\
\hline E33 & 4 & 3 & 4 & 4 & 3 & 3 & - & + & - & - & - \\
\hline Feng 05-394 & 4 & 3 & 4 & 4 & 3 & 4 & - & - & - & - & - \\
\hline Feng 1124 & 3 & 2 & 3 & 0 & 3 & 3 & - & - & - & + & - \\
\hline Fengmai 13 & 4 & 3 & 4 & 3 & 4 & 4 & - & - & - & - & - \\
\hline Fengmai 24 & 4 & 4 & 4 & 4 & 4 & 4 & - & - & - & - & - \\
\hline Fengmai 34 & 3 & 3 & 4 & 4 & 4 & 4 & - & - & - & - & - \\
\hline Fengmai 35 & 4 & 2 & 0 & 3 & 3 & 3 & + & - & - & - & - \\
\hline Fengmai 36 & 4 & 3 & 4 & 4 & 3 & 3 & - & - & - & - & - \\
\hline Fengmai 37 & 4 & 0 & 2 & 3 & 0 & 3 & - & - & - & - & - \\
\hline Fengmai 38 & 4 & 0 & 0 & 4 & 3 & 4 & - & - & - & - & - \\
\hline Fengmai 39 & 4 & 3 & 4 & 2 & 4 & 3 & - & - & - & - & - \\
\hline Fengyin $03-2$ & 4 & 2 & 4 & 2 & 3 & 4 & - & - & - & + & - \\
\hline Jing 0202 & 3 & 2 & 3 & 4 & 0 & 4 & + & + & - & - & - \\
\hline Jing 06-4 & 3 & 3 & 4 & 3 & 4 & 4 & - & + & - & - & - \\
\hline Jingmai 11 & 4 & 0 & 0 & 3 & 4 & 3 & - & + & - & - & - \\
\hline Jingmai 12 & 4 & 3 & 4 & 4 & 3 & 4 & - & + & - & - & - \\
\hline Jingmai 14 & 4 & 4 & 3 & 4 & 4 & 4 & - & + & - & - & - \\
\hline Kun $022-222-1$ & 4 & 4 & 3 & 3 & 4 & 4 & - & - & - & - & - \\
\hline Kunmai 4 & 0 & 0 & 0 & 1 & 0 & 1 & - & - & - & - & + \\
\hline Kunmai 5 & 4 & 3 & 0 & 0 & 4 & 4 & - & + & - & - & - \\
\hline Liangmai 4 & 4 & 2 & 4 & 1 & 3 & 3 & + & + & - & - & - \\
\hline Linmai 15 & 3 & 4 & 4 & 4 & 3 & 4 & - & + & - & - & - \\
\hline Linmai 6 & 4 & 4 & 3 & 4 & 4 & 4 & - & - & - & - & - \\
\hline Mentana & 3 & 3 & 4 & 3 & 3 & 3 & - & - & - & - & - \\
\hline Mian 1971-98 & 4 & 0 & 3 & 4 & 4 & 3 & - & - & - & - & - \\
\hline Mianyang 19 & 3 & 3 & 4 & 3 & 4 & 4 & - & - & - & - & - \\
\hline Mianyang 20 & 4 & 4 & 3 & 4 & 4 & 4 & - & - & - & - & - \\
\hline
\end{tabular}




\begin{tabular}{|c|c|c|c|c|c|c|c|c|c|c|c|}
\hline Nanyuan 1 & 4 & 3 & 3 & 4 & 3 & 4 & - & - & - & - & - \\
\hline R101 & 3 & 4 & 3 & 3 & 3 & 3 & - & - & - & - & - \\
\hline R57 & 4 & 0 & 4 & 3 & 2 & 4 & - & + & - & - & - \\
\hline Wenmai 11 & 4 & 0 & 4 & 3 & 1 & 4 & + & + & - & - & - \\
\hline Wenmai 12 & 4 & 3 & 1 & 2 & 4 & 3 & - & + & - & - & - \\
\hline Yimai 1 & 4 & 4 & 4 & 4 & 4 & 4 & - & - & - & - & - \\
\hline Yimai 10 & 3 & 4 & 4 & 4 & 4 & 4 & - & - & - & - & - \\
\hline Yimai lines 2003-13 & 1 & 0 & 1 & 0 & 1 & 1 & - & - & - & - & - \\
\hline Yimai lines 2003-27 & 0 & 1 & 1 & 0 & 1 & 0 & - & - & - & - & - \\
\hline Yixi 2003-64 & 0 & 0 & 1 & 0 & 1 & 0 & - & - & - & - & + \\
\hline Yumai 1 & 4 & 4 & 4 & 4 & 4 & 4 & - & + & - & - & - \\
\hline Yumai 3 & 3 & 2 & 4 & 3 & 3 & 4 & + & + & - & - & - \\
\hline Yunmai 101 & 3 & 4 & 3 & 3 & 4 & 4 & - & + & - & - & - \\
\hline Yunmai 11-12 & 4 & 3 & 4 & 4 & 3 & 4 & - & - & - & - & - \\
\hline Yunmai 29 & 4 & 3 & 4 & 3 & 4 & 4 & - & - & - & - & - \\
\hline Yunmai 39 & 3 & 3 & 2 & 3 & 4 & 4 & - & - & - & + & - \\
\hline Yunmai 42 & 3 & 3 & 4 & 3 & 3 & 4 & - & - & - & + & - \\
\hline Yunmai 43 & 4 & 4 & 3 & 3 & 4 & 1 & - & - & - & - & - \\
\hline Yunmai 47 & 3 & 4 & 4 & 4 & 3 & 3 & - & - & - & - & - \\
\hline Yunmai 48 & 2 & 4 & 3 & 0 & 4 & 4 & - & - & - & - & - \\
\hline Yunmai 51 & 4 & 0 & 4 & 3 & 3 & 3 & + & - & - & - & - \\
\hline Yunmai 52 & 4 & 4 & 3 & 4 & 3 & 4 & - & - & - & - & - \\
\hline Yunmai 53 & 3 & 2 & 3 & 0 & 0 & 1 & - & - & - & - & - \\
\hline Yunmai 54 & 4 & 3 & 4 & 4 & 3 & 4 & - & - & - & - & - \\
\hline Yunmai 56 & 3 & 0 & 0 & 4 & 1 & 3 & - & - & - & - & - \\
\hline Yunmai 57 & 4 & 4 & 0 & 3 & 0 & 4 & - & - & - & - & - \\
\hline Yunxuan 3 & 4 & 3 & 3 & 4 & 4 & 4 & - & - & - & - & - \\
\hline Yunza 5 & 4 & 4 & 3 & 3 & 3 & 3 & - & - & - & - & - \\
\hline Yunza 6 & 4 & 4 & 4 & 3 & 4 & 3 & - & - & - & - & - \\
\hline Yunza 7 & 4 & 3 & 4 & 4 & 3 & 4 & - & - & - & - & - \\
\hline
\end{tabular}


